- to Foc-TR4, either by classical breeding or genetic engineering, has so far been limited. The wild Asian banana Musa acuminata malaccensis - the genome of which was published last year (A. D'Hont Nature 488, 213-217;2012) - seems to be resistant, and researchers are experimenting with putting its resistance genes into the Cavendish. The resulting transgenic specimens have been in field trials for 18 months on contaminated ground in Australia, and are looking "very promising", says James Dale, director of the Centre for Tropical Crops and Biocommodities at Queensland University of Technology in Brisbane, Australia. But he cautions that the full results are not yet in.

For those who buy their bananas in supermarkets, the Cavendish may well be the only variety they know. But exports of the cultivar account for only about $13 \%$ of the 150 million or so tonnes of bananas and cooking bananas (plantains) produced annually. Industrial farms growing a single Cavendish cultivar are at a high risk of Foc-TR4 infestation, but the fungus poses less of a threat to the bulk of the bananas that provide a staple for some 400 million people worldwide.

Most of the bananas important for the food supply are grown by smallholder farmers in low-income countries and consumed locally. Hundreds of cultivars are farmed, and this biodiversity is an important rampart against disease. Researchers do not yet have a full picture of the susceptibility of these varieties, but many cultivars are likely to be resistant to Foc-TR4 because they are biologically different to the Cavendish.

For his part, Dale is trying to engineer Gros Michel bananas for resistance to the original Foc strain. The Cavendish is bland by comparison and it bruises more easily. Dale would like to see Gros Michel on supermarket shelves again. "It's such a superior banana to Cavendish. To bring it back would be wonderful." - SEE CORRESPONDENCE P.218

\section{FRUIT THREAT}

A fungus strain that kills banana plants has been detected in three of the world's top producers of the fruit.

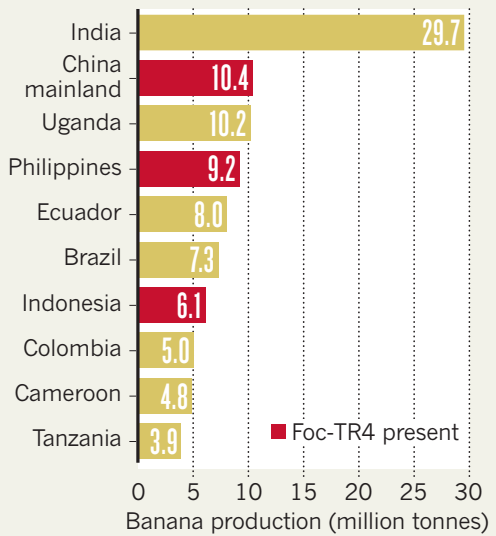

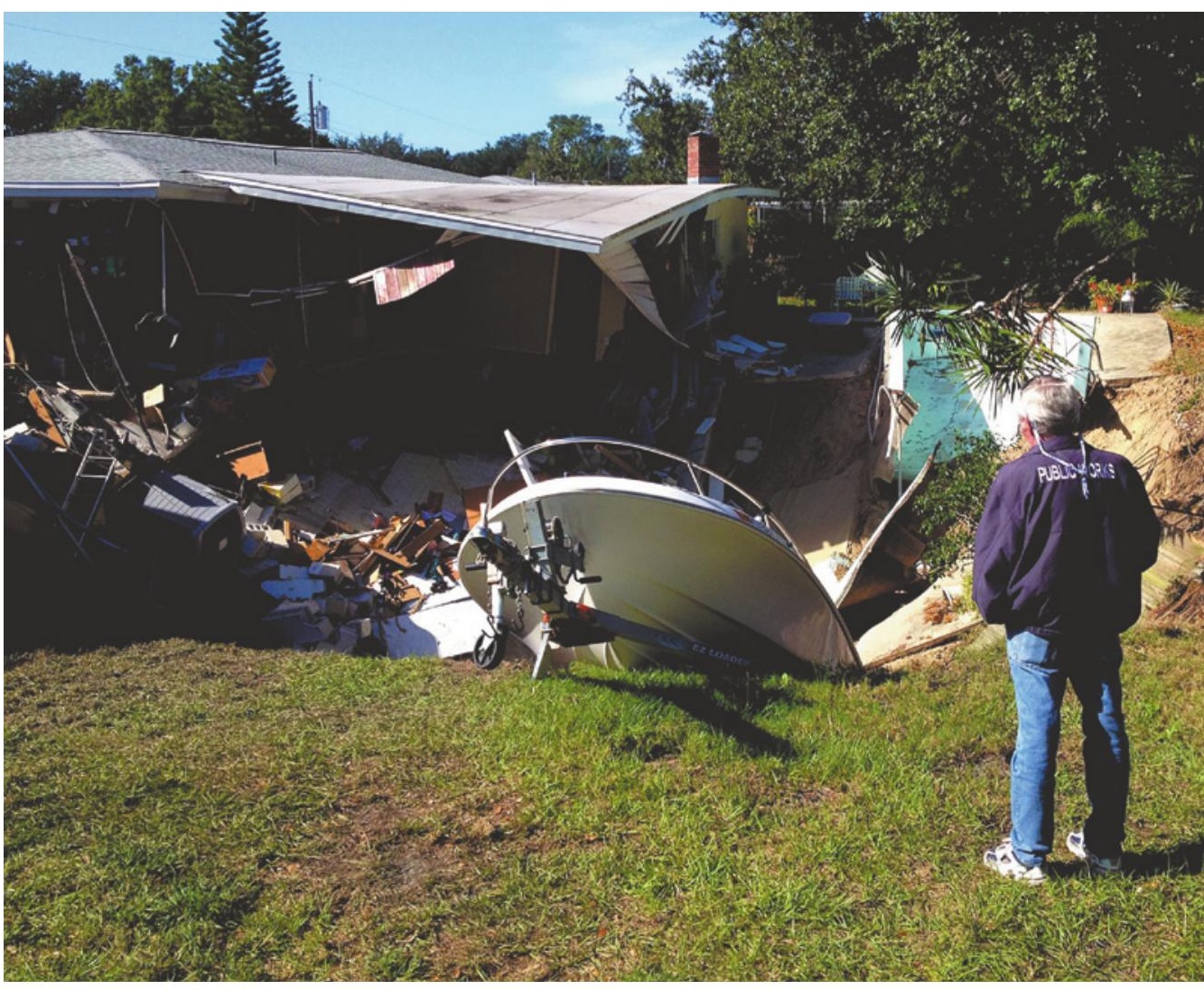

Grounds for concern: a sinkhole in Florida devoured a pool, a boat and two houses on 14 November.

GEOLOGY

\title{
Florida forecasts sinkhole burden
}

\section{Predictive model will map areas vulnerable to collapse.}

\section{BY ALEXANDRA WITZE}

A 21-metre-wide hole in the ground opened up behind two homes last month in Dunedin, Florida, swallowing a swimming pool, a boat and eventually both houses. Days later, geologist Clint Kromhout found himself on the phone with a woman who lived nearby. She was upset, and ready to sell her house and leave the state.

Kromhout, who works with the Florida Geological Survey in Tallahassee, gave her his usual speech: anyone here should get used to sinkholes. In the easily erodible karst terrain of Florida, they strike regularly and seemingly at random. In August, sinkholes collapsed a three-storey holiday villa near Disney World. In February, a sinkhole in Seffner entombed a man while he slept. "If you live in Florida, a bunch of things are given: sunshine, beaches, hurricanes - and sinkholes," Kromhout says.
But this autumn, he and his colleague Alan Baker began to develop a weapon in the battle against their state's geology: a predictive map. By 2016, they expect to have a state-wide map that is colour-coded by category of sinkhole vulnerability at a scale of around 1 kilometre. "We want to produce a map that is scientifically defensible and not just based on some expert's opinion," says Kromhout.

The result will feed into the multimilliondollar battle between homeowners and insurance companies in Florida, where coverage for 'catastrophic ground cover collapse' is required but damage claims are often denied. It could also set a new standard for sinkholevulnerability studies in other states and countries, which typically compile maps of existing sinkholes but do not have predictive maps showing where new ones might form. Carbonate rocks such as limestone, which are prone to being chewed up into 
Swiss-cheese-like karst terrain, cover 13\% of the planet's land (see 'A sinking feeling'), and the problems that they create plague not only Florida but also much of the United States, Europe, China and beyond.

How sinkholes form is well known. In one common scenario, naturally acidic rainwater percolates through carbonate rock and dissolves it to form caves and other underground openings. Overlying sediments then collapse into the void, forming a sinkhole.

Florida is particularly vulnerable because its layers of limestone are at most only a few tens of millions of years old; they have not had time to become compressed and more resistant to dissolution and erosion. In places, interleaved layers of sand from ancient beaches enhance the erosion of limestone. Layers of clay near the surface are strong enough to hold sediments together even as voids form beneath them, but when the clays do give way, the chasms can be immense. Drought, hurricanes and the pumping of groundwater cause fluctuations in the water table - a further factor in the state's propensity for sinkholes. "There are different styles and flavours of karst, but Florida is an animal all its own," says Daniel Doctor, a karst expert at the US Geological Survey in Reston, Virginia.

In June 2012, the issue came to the fore after Tropical Storm Debby swept across the state, inundating the ground after months of drought and causing hundreds of sinkholes to appear. That's when the state division of emergency management contacted the Florida Geological Survey to see what it could do to prepare for future outbreaks.

The state survey has mapped sinkholes for more than a century, but the records are patchy and biased towards urban and suburban areas, where sinkholes are more likely to cause property damage when they occur. The survey keeps a list of almost 3,500 reported depressions, but some of those are unlikely to be 'proper' sinkholes, says Jonathan Arthur, director of the state survey. Many could be other types of collapses caused by buried wood piles or old septic tanks that caved in.

The sinkhole maps are also, by definition, retrospective. But, funded by almost US\$1.1 million from the state and the Federal Emergency Management Agency, Kromhout and Baker are using a technique that can

\section{A SINKING FEELING}

Carbonate rocks cover $13 \%$ of the world's land surface and are susceptible to erosion by running water. The resulting karst terrain tends to have high numbers of caves and sinkholes.

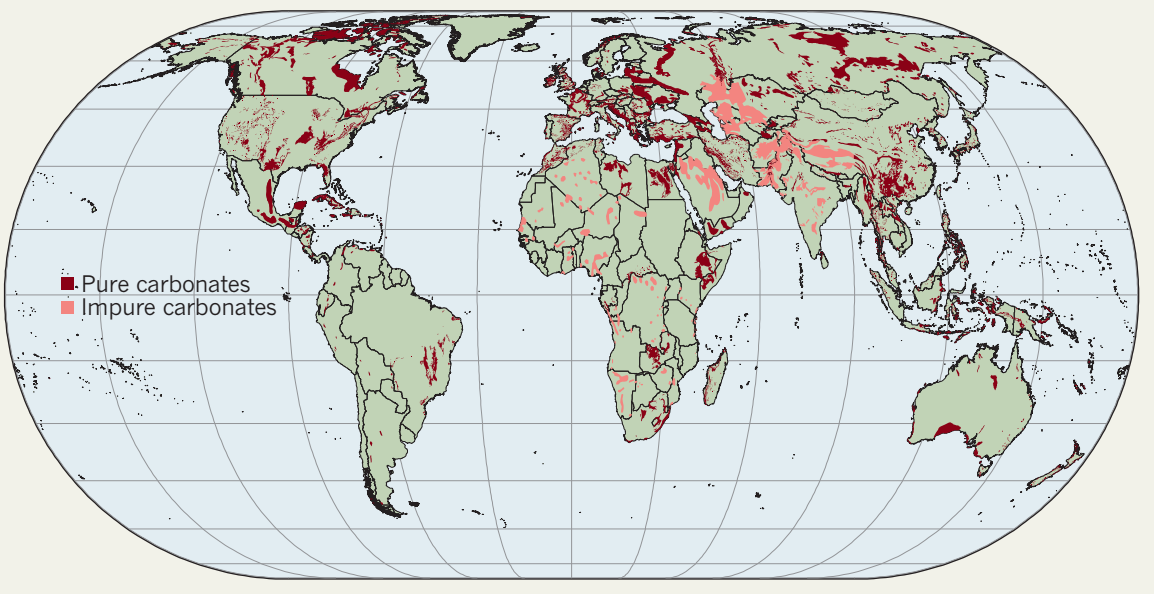

predict future occurrences. Called 'weights of evidence', the three-decade-old method has its roots in the diagnosis of medical illnesses, and it has also been used in environmental settings such as mineral exploration. First, researchers collect information that is already held in various databases - factors such as the depth of limestone and the water table, and the presence of clays and streams. A computer model integrates the information and spits out a prediction of where sinkholes are most likely to form. Then the sites

"There are different styles and flavours of karst, but Florida is an animal all its own." of known sinkholes are used to test the model's predictions.

At 1-kilometre resolution, the map will still not be able to tell a property owner if a hole is likely to appear below his or her shed. But it should prove helpful to emergency managers who are seeking clues as to where the next sinkhole swarm might form. Insurance companies are also likely to combine the map with their own studies when setting insurance premiums in different regions, Arthur says.

Officials at all levels of government are looking to incorporate more solid scientific information into sinkhole policies, says Robert Denton, a senior geologist with
GeoConcepts Engineering in Ashburn, Virginia. For instance, Virginia is looking to adopt standardized guidelines that any expert hired to assess a possible sinkhole would have to follow. And next year, the US Geological Survey is expected to release the first digitized version of its National Karst Map - a step that could push other states to develop predictive maps.

Across the globe, other governments have embarked on related steps. The Vaud canton in western Switzerland has been mapping sinkholes within its borders, in part to improve insurance requirements on public buildings in case of sinkhole damage. In Italy, scientists at the Institute of Research for Hydrogeological Protection (IRPI) in Bari have been compiling a database of sinkhole distribution.

The Italian catalogue, which currently includes 900 sinkholes, is the first there to incorporate time of occurrence as well as location, says Mario Parise of the IRPI. That's crucial for planning, he says, because local officials want to know not only where a sinkhole might form but also when.

For the Florida team, plenty of work remains. This week, the researchers plan to explore state parks, checking to see whether circular features shown on maps really are sinkholes. From there, it's a matter of hard work, then waiting to see whether they can predict the next hole in the ground.

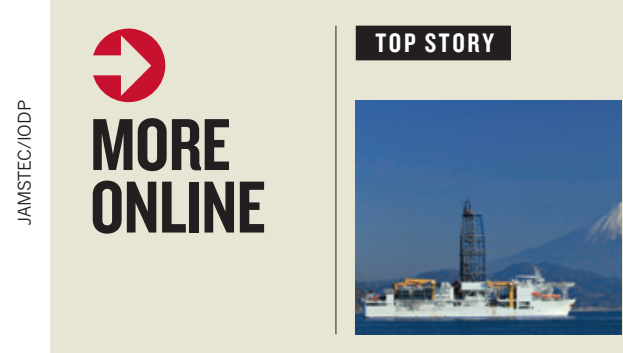

Thin

clay fault caused by earthquake and tsunami. go.nature.com/ t2zkdy

\section{MORE NEWS}

- Dyslexia linked to miscommunication between brain centres go.nature.com/mpba3p

- Large-scale solar convection cells confirmed go.nature.com/jecc7m

- Mortality and fertility mapped across phyla go.nature.com/hz7oy7

\section{NATURE PODCAST}

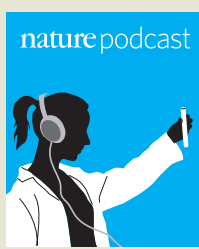

Lifespans across the tree of life; lizards breathe like birds; and the medical-isotopes crisis nature.com/ nature/podcast 